\title{
$\alpha$-TEA-induced death receptor dependent apoptosis involves activation of acid sphingomyelinase and elevated ceramide- enriched cell surface membranes
}

\author{
Jing $\mathrm{Li}^{1 \dagger}$, Weiping $\mathrm{Yu}^{1 \dagger}$, Richa Tiwary ${ }^{1}$, Sook-Kyung Park ${ }^{1}$, Ailian Xiong ${ }^{2}$, Bob G Sanders ${ }^{1}$, Kimberly Kline ${ }^{2^{*}}$
}

\begin{abstract}
Background: Alpha-tocopherol ether-linked acetic acid ( $\alpha$-TEA), an analog of vitamin E (RRR-alpha-tocopherol), is a potent and selective apoptosis-inducing agent for human cancer cells in vivo and in vitro. $\alpha$-TEA induces apoptosis via activation of extrinsic death receptors Fas (CD95) and DR5, JNK/p73/Noxa pathways, and suppression of antiapoptotic mediators Akt, ERK, c-FLIP and survivin in breast, ovarian and prostate cancer cells.

Results: In this study, we demonstrate that $\alpha$-TEA induces the accumulation of cell surface membrane ceramide, leading to co-localization with Fas, DR5, and FADD, followed by activation of caspases-8 and -9 and apoptosis in human MDA-MB-231 breast cancer cells. $\alpha$-TEA treatment leads to increased acid sphingomyelinase (ASMase) activity by 30 min, peaking at 4 hrs, which is correlated with ASMase translocation from cytosol to the cell surface membrane. Functional knockdown of ASMase with either the chemical inhibitor, desipramine, or siRNA markedly reduces $\alpha$-TEA-induced cell surface membrane accumulation of ceramide and its co-localization with Fas, DR5, and FADD, cleavage of caspases-8 and -9 and apoptosis, suggesting an early and critical role for ASMase in $\alpha$-TEAinduced apoptosis. Consistent with cell culture data, immunohistochemical analyses of tumor tissues taken from $\alpha$ TEA treated nude mice bearing MDA-MB-231 xenografts show increased levels of cell surface membrane ceramide in comparison to tumor tissues from control animals.
\end{abstract}

Conclusion: Taken together, these studies demonstrate that ASMase activation and membrane ceramide accumulation are early events contributing to $\alpha$-TEA-induced apoptosis in vitro and perhaps in vivo.

\section{Background}

Specialized domains of cell surface membranes termed lipid rafts/platforms or lipid microdomains play a key role in the spatial organization of receptors and signaling molecules [1-3]. Ceramide-enriched lipid microdomains can be formed by increased amounts of ceramide in cell surface membranes which is regulated by sphingomyelinase (SMase) hydrolysis of raft-associated sphingomyelin to ceramide $[2,3]$. Once ceramide-enriched microdomains are formed, Fas/FasL and DR5/TRAIL as well as other signaling mediators become clustered and

\footnotetext{
* Correspondence: k.kline@mail.utexas.edu

+ Contributed equally

2Department of Nutritional Sciences/A2703, University of Texas at Austin,

Austin, TX 78712, USA

Full list of author information is available at the end of the article
}

can be activated in either a ligand-dependent or -independent manner [4-6]. Clustering of Fas or DR5 can result in rapid association of these receptors with adapter protein FADD [7], which recruits the initiation caspase- 8 to its death effector domain, initiating apoptosis via death inducing signaling complex (DISC) [8]. Prevention of raft reorganization into larger platforms by inactivation of acid sphingomyelinase (ASMase), renders cells resistant to Fas clustering and apoptosis [9], indicating that ASMase/ceramide plays an important role in death receptor-mediated apoptosis.

$\alpha$-TEA (RRR-alpha-tocopherol ether-linked acetic acid analog), a derivative of vitamin E (RRR-alpha-tocopherol), is a potent pro-apoptotic agent for a variety of human cancer cells, including breast cancer cells in vivo and in vitro [10-24]. $\alpha$-TEA does not induce apoptosis 
in normal human mammary epithelial cells (HMEC) or immortalized, nontumorigenic breast cells (MCF-10A cells) [17] and produces no signs of toxicity when given to mice $[10,11,19,24,25]$. Previous studies utilizing various functional knockdown strategies (siRNA, neutralizing antibodies, transfection of dominant negative proteins and small chemical inhibitors) show that $\alpha$ TEA-induced apoptosis in human breast, ovarian and prostate cancer cells is mediated by Fas and DR5 death receptor signal transduction via FADD or Daxx and involves both caspase- 8 and mitochondrial-dependent signal transduction events $[15,16,18,20,21]$. However, mechanisms involved in $\alpha$-TEA induced Fas- and DR5dependent apoptotic signaling are not fully understood. Here we report that $\alpha$-TEA initiates activation of ASMase via translocation from the cytosol to the cell surface membrane, leading to accumulation and aggregation of membrane ceramide domains enriched with death signaling mediators; Fas, DR5 and their adaptor FADD, as an essential early event in $\alpha$-TEA induced Fas and DR5 dependent apoptosis.

\section{Materials and methods \\ Chemicals}

$\alpha$-TEA (F.W. $=488.8 ; 40 \mu \mathrm{M}$ ) was dissolved in ethanol as stock solution as described previously [10]. Desipramine, an ASMase inhibitor, GW4869, a neutral SMase (NSMase) inhibitor, and fumonisin B1, a ceramide synthase inhibitor, were obtained from Sigma-Aldrich (St. Louis, MO). Myriocin, a serine palmitoyltransferase inhibitor of the de novo ceramide synthesis pathway, was obtained from BioMol (Plymouth Meeting, PA).

\section{Cell Culture}

Triple-negative (ER', $\mathrm{PR}^{-}$, Her-2-) MDA-MB-231 human invasive ductal carcinoma, basal-like breast cancer cells (American Type Culture Collection, Manassas, VA) were cultured in MEM media with $10 \%$ FBS. For experiments, FBS was reduced to $2 \%$. All cells were plated at $1.5 \times 10^{5}$ cells/well in 12 well plates for apoptosis analyses, $3 \times 10^{5}$ cells/well in 6 well plates for immunofluorescence staining and FACS analyses, and $2 \times 10^{6}$ cells $/ 100 \mathrm{~mm}^{2}$ or $6 \times 10^{6}$ cells $/ 150 \mathrm{~mm}^{2}$ dishes for western blot analyses. Cells were allowed to attach overnight before treatment initiation. The cells were treated with $\alpha$-TEA at $40 \mu \mathrm{M}$ with equivalent level of solvent $(0.1 \%$ ethanol) serving as vehicle control (VEH).

\section{Quantification of apoptosis}

Apoptosis was quantified by Annexin V-FITC/PI assay (Invitrogen, Carlsbad, CA) following manufacturer's instructions. The Annexin V-FITC/PI assay measures amount of phosphatidylserine on the outer surface of the plasma membrane (a biochemical alteration unique to membranes of apoptotic cells) and amount of propidium iodide (PI), a DNA binding dye that does not cross the plasma membrane of viable cells but readily enters dead cells or cells in the late stages of apoptosis. Fluorescence was measured using Fluorescence Activated Cell Sorter (FACS) analyses with a FACSCalibur flow cytometer. Data were analyzed using CellQuest software (BD Biosciences, San Jose, CA). Cells displaying phosphatidylserine on their surface (positive for Annexin-V fluorescence) were considered to be apoptotic.

\section{Small interfering RNA (siRNA) transfection}

A scrambled RNA duplex that does not target any known genes was used as the non-specific negative control for RNAi (referred to as control siRNA). Transfection of MDA-MB-231 cells with siRNAs to ASMase or control (Ambion, Austin, TX) was performed in 100 $\mathrm{mm}^{2}$ cell culture dishes at a density of $2 \times 10^{6}$ cells/dish using Lipofectamine-2000 (Invitrogen) and siRNA duplex, resulting in a final siRNA concentration of 30 $\mathrm{nM}$ following the company's instructions. One day after transfection initiation, the cells were re-cultured in 100 $\mathrm{mm}^{2}$ dishes at $2 \times 10^{6}$ cells/dish and incubated for 1 day followed by treatments.

\section{Western Blot analyses}

Whole cell protein extracts were prepared and examined by western blotting as described previously [26]. Proteins at 30-50 $\mu \mathrm{g} /$ lane were separated by SDS-PAGE and transferred to nitrocellulose (Optitran BA-S supported nitrocellulose, Schleicher and Schuell, Keene, $\mathrm{NH})$. Antibodies $(1 \mu \mathrm{g} / \mathrm{ml})$ to the following proteins were used: poly (ADP-ribose) polymerase (PARP) (Santa Cruz Biotechnology, Santa Cruz, CA), caspase- 8 and caspase-9 (Cell Signaling Technology, Beverly, MA), and glyceraldehyde-3-phosphate dehydrogenase (GAPDH; made in house). Horseradish peroxidase conjugated goat-anti-rabbbit or goat-anti-rabbbit secondary antibodies (1:2000 dilution) (Jackson ImmunoResearch Laboratories, Rockford, IL) was used.

\section{Immunofluorescent staining detection of ASMase, ceramide, DR5, Fas and FADD}

Cellular location of ASMase, ceramide, DR5, Fas and FADD was determined using immunofluorescent staining. Treated and control cells were washed two times with PBS and fixed with fresh $4 \%$ paraformaldehyde in PBS for $15 \mathrm{~min}$ at room temperature. After 3 washes with PBS, cells were permeated with $0.1 \%$ Triton X-100 for $15 \mathrm{~min}$ at room temperature followed by incubating the cells with blocking buffer (2\% FBS in PBS) for $1 \mathrm{hr}$, and then incubating the cells with reaction buffer $(1 \%$ FBS in PBS) overnight at $4^{\circ} \mathrm{C}$ with antibodies $(20 \mu \mathrm{g} / \mathrm{ml})$ 
to DR5 (Abcam Inc, Cambridge, UK), FADD (BD Biosciences, San Jose, CA), ASMase and Fas (Santa Cruz Biotechnology), and antibody $(4 \mu \mathrm{g} / \mathrm{ml})$ to ceramide (Sigma-Aldrich). Samples were washed three times with PBS and stained for $1 \mathrm{hr}$ with Texas Red donkey antirabbit IgG (Santa Cruz Biotechnology) for DR5, Alexa Fluor 594 goat anti-mouse IgG (Invitrogen) for Fas and FADD, Alexa Fluor 488 goat anti-mouse IgM and FITCconjugated rabbit anti-goat IgG (Jackson ImmunoResearch Laboratories) for ceramide and ASMase at $10 \mu \mathrm{g} /$ $\mathrm{ml}$, respectively, in reaction buffer. Cells were washed three times with PBS. Images were acquired using fluorescent microscopy or laser-scanning confocal microscope.

\section{Detection of ceramide expression in cell surface membranes of living cells}

The expression of cell surface membrane ceramide was determined by immunostaining analyses using FACS or fluorescent microscopy. $2 \times 10^{6}$ cells were collected, washed in ice-cold PBS, and blocked with blocking buffer (2\% FBS in PBS) for $20 \mathrm{~min}$ on ice. Cells were rewashed and incubated for $1 \mathrm{hr}$ with $4 \mu \mathrm{g} / \mathrm{ml}$ monoclonal ceramide antibody (15B4, Sigma) on ice, followed by icecold PBS washing and incubation with Alexa fluor 488 goat anti-mouse IgM at $10 \mu \mathrm{g} / \mathrm{ml}$ on ice for $30 \mathrm{~min}$. After two PBS washes, cells were analyzed immediately using a FACScan flow cytometer or by immunofluorescence microscopy for cell surface membrane ceramide.

\section{ASMase Activity Assay}

ASMase activity was determined using an acid sphingomyelinase assay kit (Echelon Biosciences Inc. Salt Lake City, UT) following company's instructions. Cells were disrupted in ice-cold lysis buffer [150 mM NaCl, $50 \mathrm{mM}$ Tris $\mathrm{pH} 7.4,0.6 \%$ Triton X-100, and protease inhibitor cocktail (Sigma-Aldrich)] for $20 \mathrm{~min}$. Cellular debris was removed after centrifugation at 10,000 $\times \mathrm{g}$ for $5 \mathrm{~min}$, and $20 \mu \mathrm{g}$ protein was used to determine ASMase activity. Reaction was stopped after incubation at $37^{\circ} \mathrm{C}$ for 2 hrs and analyzed using a fluorescence plate reader at $260 \mathrm{~nm}$ excitation and $460 \mathrm{~nm}$ emission.

\section{Immunohistochemical detection of membrane ceramide} Archived formalin fixed tumor tissue from a MDA-MB231 xenograft study [27] was used to determine if $\alpha$-TEA induces elevated membrane ceramide in vivo. Mice were euthanized after 24 days of $\alpha$-TEA dietary treatment (378 mg $\alpha$-TEA $/ \mathrm{kg}$ diet). Immediately upon collection, tumors were fixed in formalin and archived for immunohistochemical analyses [27]. Deparaffinized 5 micron sections were examined by IHC employing a monoclonal antibody against ceramide (MID 15B4; Sigma-Aldrich). Three tumors from control and $\alpha$-TEA treatment groups were analyzed. Deparaffinized sections were placed in $10 \mathrm{mM}$ sodium citrate buffer ( $\mathrm{pH}$ 6.0) and boiled $10 \mathrm{~min}$ for antigen unmasking. After rinsing, sections were placed in PBS followed by incubating with blocking buffer (2\% FBS, $0.3 \%$ Triton X-100 in PBS) for $1 \mathrm{hr}$. After removal of blocking buffer, cells were incubated with primary mouse anti-ceramide antibody $(4 \mu \mathrm{g} / \mathrm{ml}$ in $1 \% \mathrm{FBS} / \mathrm{PBS})$ or mouse IgM $(10 \mu \mathrm{g} / \mathrm{ml}$ for negative control) overnight at $4^{\circ} \mathrm{C}$. After 3 washes with PBS for $10 \mathrm{~min}$ each, the sections were stained with DakoCytomation LSAB + System-AP following the company's instruction (Dako Carpinteria, CA) and DAPI.

\section{Statistical Analysis}

The student's $t$-test was used to determine statistical differences between treatment and control values. Differences were considered statistically significant at $p<0.05$.

\section{Results}

$\alpha$-TEA induces apoptosis in MDA-MB-231 human breast cancer cells

$\alpha$-TEA induces MDA-MB-231 cells to undergo apoptosis in a time dependent manner as measured by FACS/ Annexin V/PI analyses. Apoptosis was detected at $15 \mathrm{hrs}$ after treatment with $40 \mu \mathrm{M} \alpha$-TEA (Figure 1A \&1B). $\alpha$-TEA treatment for 9 hrs did not show a significant increase in percentage of apoptotic cells in comparison with VEH control, whereas $\alpha$-TEA treatments for 15 and 24 hrs produced a high percentage of apoptotic cells, approximately, $33 \%$ and $57 \%$, respectively, suggesting that apoptosis occurred between 9-15 hrs. Data from western immunoblotting analyses show cleavage of caspases- 8 and -9 in lower levels at 9 hrs, and higher levels at 15 and $24 \mathrm{hrs}$ after treatment (Figure 1C). Cleavage of PARP, an apoptotic marker, was detected at 15 and $24 \mathrm{hrs}$ after treatment (Figure 1C).

\section{$\alpha$-TEA induces increased level of ceramide in cell surface membrane}

To see if $\alpha$-TEA induces an increased level of ceramide in the cell surface membrane, membrane ceramide expression in $\alpha$-TEA treated MDA-MB-231 cells was determined by fluorescent microscopy or FACS analyses of cells stained for ceramide (Figure 2). Microscopic analyses showed that ceramide was aggregated in cell surface membranes starting as early as $4 \mathrm{hrs}$ and continued to be elevated at $15 \mathrm{hrs}$ after $\alpha$-TEA treatment in comparison with VEH control (Figure 2A). In agreement with the microscopic morphological data, FACS analyses showed that cell surface membrane level of ceramide in $\alpha$-TEA treated cells were increased at 4 and 15 hrs (Figure 2B). These data show that $\alpha$-TEA induces increased and prolonged levels of ceramide, which is aggregated in the cell surface membrane as early as 4 hrs. 


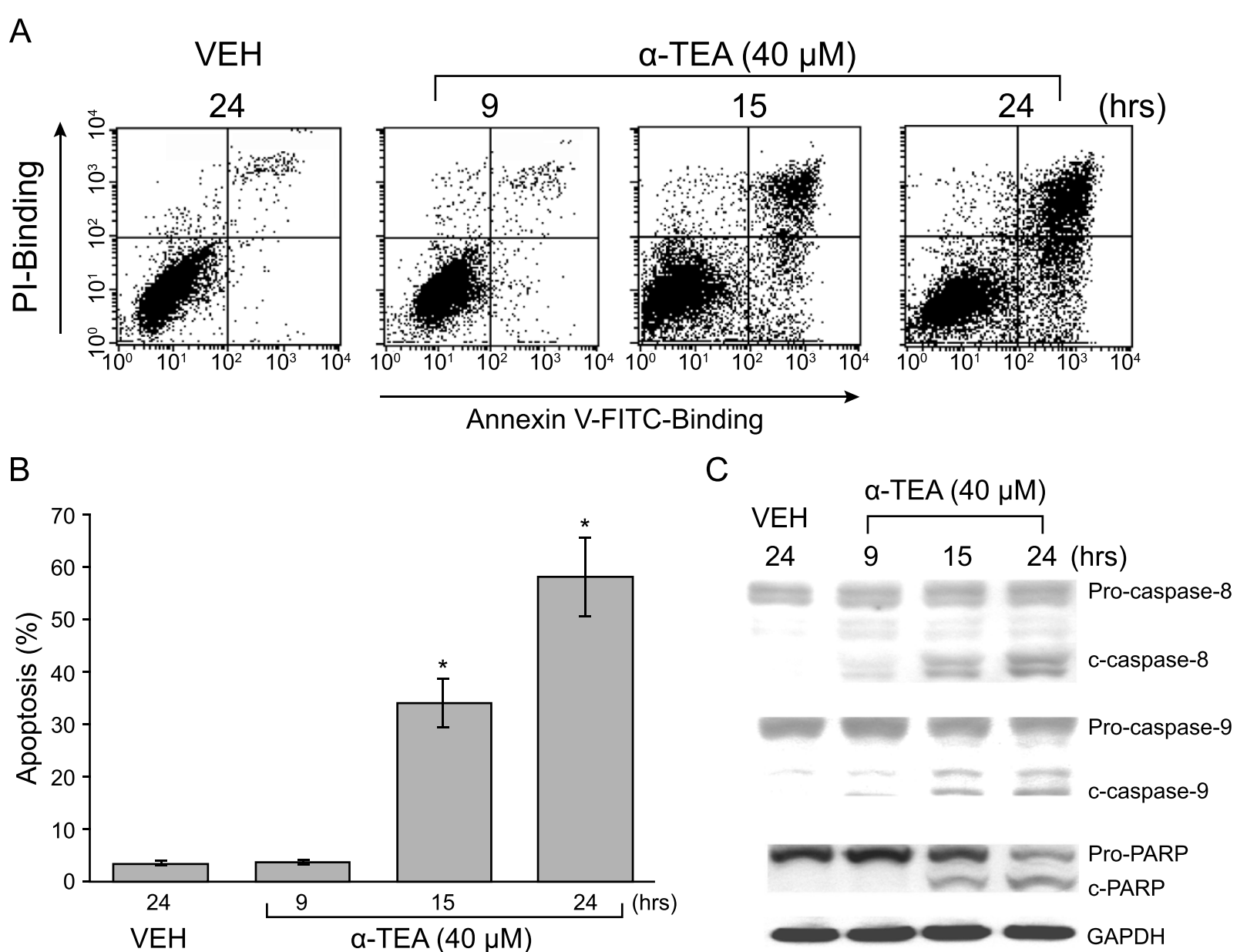

Figure $1 \boldsymbol{\alpha}$-TEA induces apoptosis in human breast cancer cells. A \& B, MDA-MB-231 cells were treated with $40 \mu \mathrm{M} \boldsymbol{\alpha}$-TEA for 9,15 , and 24 hrs. Apoptosis was determined by FACS/Annexin $V$ assay (A) and depicted in graphic form (B). C, Western blot analyses were used to detect cleavage of caspases-8, -9 and PARP. Data in A \& $C$ are representative of three experiments. Data in B is presented as means \pm S.D. of three independent experiments.

$\alpha$-TEA induces accumulation of DR5, Fas and FADD in elevated ceramide-enriched membrane

The effects of $\alpha$-TEA on the expression of cell membrane death receptors Fas, DR5 and death adaptor protein FADD as well as membrane ceramide were examined using immunofluorescent staining procedures (Figure 3A, B, \&3C). $\alpha$-TEA induced increased levels of ceramide in cell surface membrane in comparison to VEH control and overlay (merge) of ceramide and DAPI-stained nuclei with DR5, Fas, or FADD showed the death mediators to be co-localized with ceramide (Figure 3A, B, \&3C). These data demonstrate that $\alpha$ TEA induced accumulation of DR5, Fas and FADD in ceramide enriched cell surface membrane, suggesting ceramide may be playing an important role in $\alpha$-TEAinduced apoptosis.
$\alpha$-TEA activation of ASMase is an early event

To determine if ASMase is activated by $\alpha$-TEA, ASMase activity was measured using a colorimetric sphingomyelinase assay kit. ASMase activity was increased from $105 \%$ at $30 \mathrm{~min}$ to a peak of $143 \%$ at $4 \mathrm{hrs}$ and continued to be elevated at $9 \mathrm{hrs}$ after $\alpha$-TEA treatment in comparison to $\mathrm{VEH}$ control (control = 100\%) (Figure $4 \mathrm{~A})$. It is well established that activation of ASMase is coupled with its translocation from intracellular compartments to the cell surface membrane [2]; therefore, we determined whether activity of ASMase was associated with relocalization of ASMase from the cytosol to the membrane. Confocal microscopic imaging revealed that $\alpha$-TEA induces ASMase relocation from punctuate cytosol location (see in VEH treated cells) to a diffuse cell surface membrane location (arrows) by $4 \mathrm{hrs}$ with 


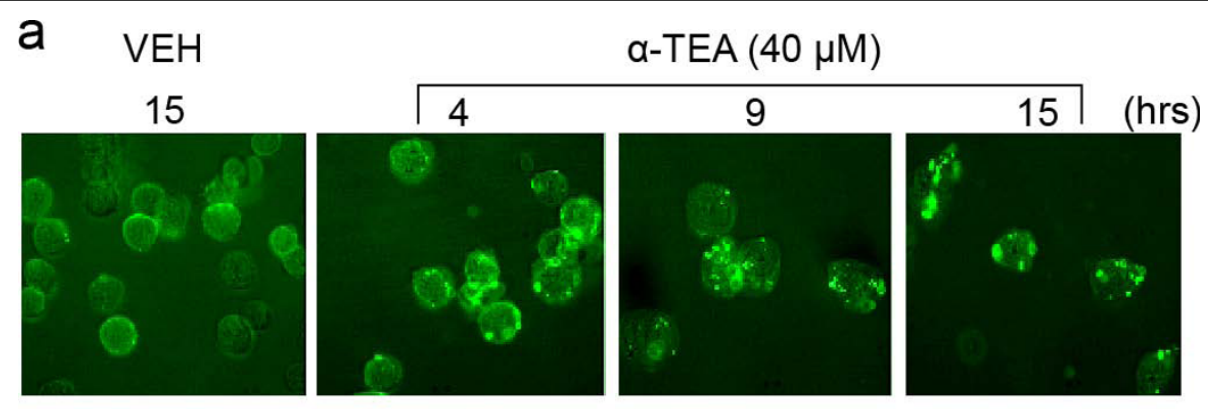

b

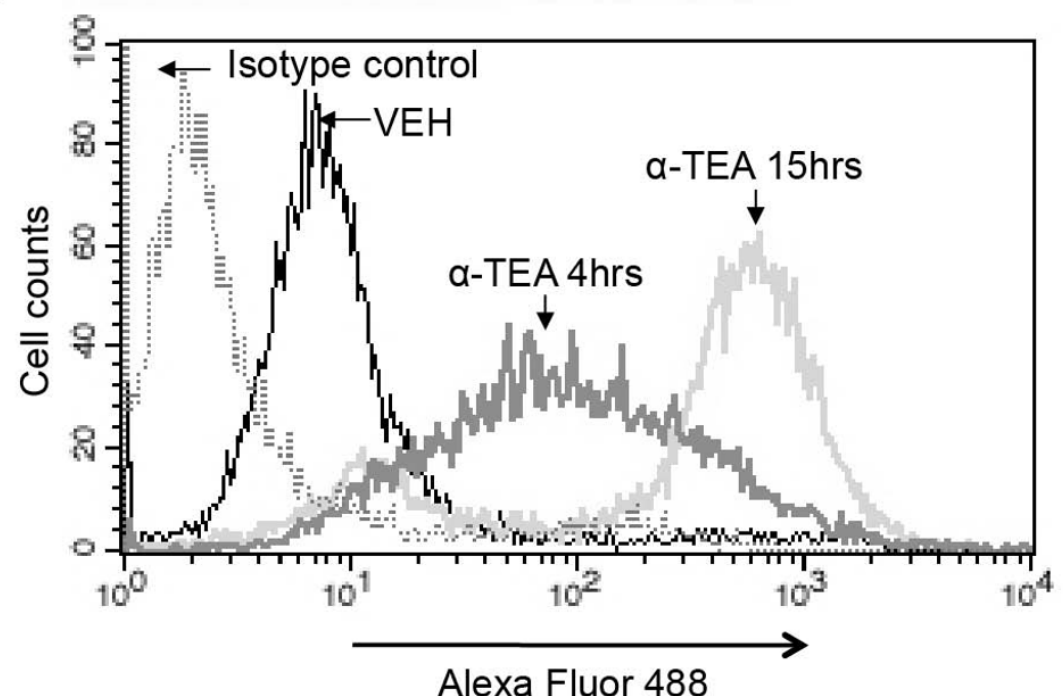

Figure $2 \alpha$-TEA induced increased levels and aggregation of ceramide in cell surface membranes. A, MDA-MB-231 cells were treated with $40 \mu \mathrm{M} \alpha$-TEA for 4, 9 and 15 hrs (15 hrs for vehicle control). The living cells were collected and immunostained with antibody to ceramide. Cellular membrane ceramide was assessed by fluorescence microscope. B, Samples from Figure 2a at 4 and 15 hrs time points were also assessed by FACS for membrane expression of ceramide. All images are representative of three independent experiments.

diffuse membrane location remaining at $9 \mathrm{hrs}$ following treatment (Figure 4B). These data demonstrate that $\alpha$ TEA activation of ASMase via translocation of it from cytosol to membrane is an early event.

\section{ASMase inhibitor desipramine blocks $\alpha$-TEA-induced apoptosis}

To investigate whether ASMase is involved in $\alpha$-TEAinduced apoptosis and if it produces increased levels of ceramide at the cell surface, the sphingomyelin hydrolysis pathway was blocked by ASMase inhibitor desipramine. Inhibition of ASMase blocked $\alpha$-TEA-induced apoptosis as documented by reduced ability of $\alpha$-TEA to induce cleavage of caspases $8 \& 9$ and PARP (Figure $5 \mathrm{~A})$. In contrast GW4869, an inhibitor of sphingomyelin hydrolysis, myriocin, an inhibitor of de novo ceramide synthesis and fumonisin B1, an inhibitor of the ceramide salvage pathway had no effect on $\alpha$-TEA-induced apoptosis (data not shown). Assessment of ASMase activity shows that desipramine blocks $\alpha$-TEA-induced increases in ASMase activity by $77 \%$ (Figure $5 \mathrm{~B}$ ), confirming that desipramine is an effective ASMase inhibitor. FACS analyses of ceramide stained cells show that desipramine blocks the increase of ceramide at the cell surface membrane in comparison with $\alpha$-TEA treated cells in the absence of ASMase inhibitor (Figure 5C), indicating that anti-ceramide antibody (15B4) is specific for recognizing membrane ceramide. Taken together, these data suggest that ASMase is involved in $\alpha$-TEAinduced apoptosis and is involved in $\alpha$-TEA-mediated increases of ceramide at the cell surface.

\section{siRNA to ASMase blocked $\alpha$-TEA-induced apoptosis}

To further confirm the role of ASMase in $\alpha$-TEAinduced apoptosis, siRNA to ASMase was used as an alternative method to knock down ASMase and to 


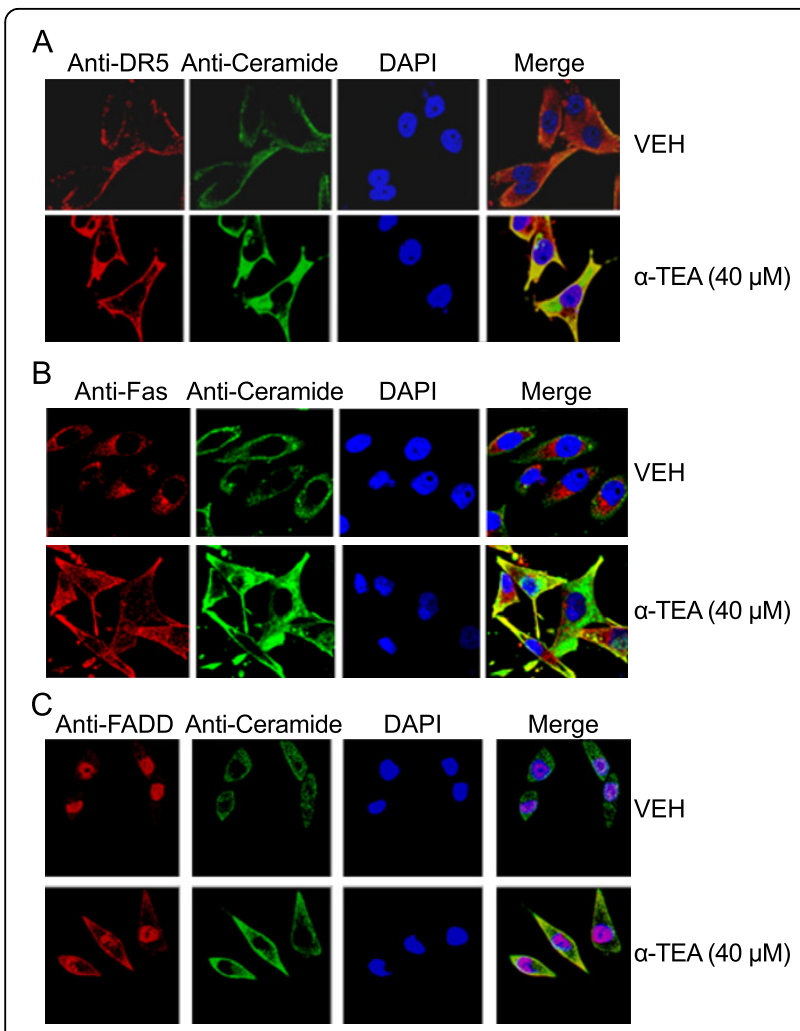

Figure $3 \alpha$-TEA induces accumulation of DR5, Fas, FADD and ceramide in cell surface membranes. $A, B$ \& $C$, Cells were treated with $40 \mu \mathrm{M} \alpha$-TEA or vehicle (VEH) for 15 hrs and cellular localization of DR5, Fas, FADD (red channel) and ceramide (green channel) were detected by immunostaining in paraformaldehyde fixed cells. Merge = overlay of ceramide (green channel) + DAPI (blue channel) + DR5 or Fas, or FADD (red channel). All data are representative images of three separate experiments.

determine the effects on $\alpha$-TEA-induced increases in cell surface ceramide and induction of apoptosis. siRNA to ASMase blocks $\alpha$-TEA-induced increase in cell surface membrane ceramide detected by anti-ceramide antibody (15B4), further indicating that this antibody is specific for recognizing membrane ceramide (Figure 6A). In addition, siRNA to ASMase significantly reduced the ability of $\alpha$-TEA to induce the cells to undergo apoptosis (Figure 6B). Western blot analyses show that the siRNA to ASMase reduced ASMase protein expression (Figure 6C), verifying silencing efficacy of siRNA to ASMase. These data further demonstrate that ASMase is involved in $\alpha$-TEA-induced apoptosis and $\alpha$-TEAmediated increase in ceramide at the cell surface.

\section{ASMase is involved in $\alpha$-TEA-induced accumulation of} DR5, Fas and FADD in elevated ceramide-enriched membrane

To see whether ASMase-mediated increase of cell surface ceramide is a contributor to $\alpha$-TEA-induced accumulation of DR5, Fas and FADD in elevated ceramide-enriched membrane, the effects of ASMase inhibitor desipramine on $\alpha$-TEA-induced co-localization of cell membrane death receptors Fas and DR5, as well as death adaptor protein FADD with ceramide were examined using immunofluorescent staining procedures (Figure $7 \mathrm{~A}, \mathrm{~B}, \& 7 \mathrm{C})$. As previously shown in Figure 3, Figure (7A, $B$ and $7 C$ ) shows that $\alpha$-TEA induces accumulation of DR5, Fas, and FADD in elevated ceramideenriched membrane in comparison to VEH control (Figure 7A, B, \&7C) and desipramine (ASMase inhibitor) reduces the ability of $\alpha$-TEA-mediated events (Figure $7 \mathrm{~A}, \mathrm{~B}, \& 7 \mathrm{C})$. These data demonstrated that ASMasemediated increase of ceramide in cell surface membrane is a contributor to $\alpha$-TEA-induced accumulation of DR5, Fas and FADD in elevated ceramide-enriched membranes.

\section{Diet supplemented with $\alpha$-TEA induced membrane ceramide accumulation in xenografted MDA-MB-231 cells} To determine if $\alpha$-TEA induces increased levels of membrane ceramide in vivo, we examined membrane ceramide expression in 5 micron sections of tumor tissue taken from $\alpha$-TEA or control treated immune compromised $\mathrm{Nu} / \mathrm{Nu}$ mice bearing MDA-MB-231 xenografts. The tumor volume and tumor weight for $\alpha$ TEA treatment group were significantly reduced in comparison to the control group after 24 days of treatment $(p<0.01)$ (Tumor volume data was published [27] and tumor weight data is shown in Figure 8A). It is important to note that no significant differences were observed in body weights between control and $\alpha$-TEA treated groups. Previously published immunohistochemical analyses showed that TUNEL positive cells in the $\alpha$ TEA treated group were significantly increased by 2.1 fold in comparison to control group [27]. Archived tumor samples were analyzed for ceramide expression by immunohistochemical analyses. Tumor tissue from $\alpha$-TEA dietary supplemented animals exhibited increased levels of membrane ceramide (detected as brown stained circles around clear; i.e., white color of nuclei following merge) in comparison with absence of membrane-localized ceramide in control tumor tissue (Figure 8B). These data show that $\alpha$-TEA increases membrane ceramide in vivo, suggesting that increased membrane ceramide plays a role in $\alpha$-TEA antitumor actions in vivo.

\section{Discussion}

$\alpha$-TEA exhibits selective anticancer properties both in vitro and in vivo [10-24]. Mechanisms whereby $\alpha$-TEA induces tumor cells to undergo apoptosis include activation of both death receptors (Fas and DR5) and JNK/ p73/Noxa pro-apoptotic pathways; as well as 

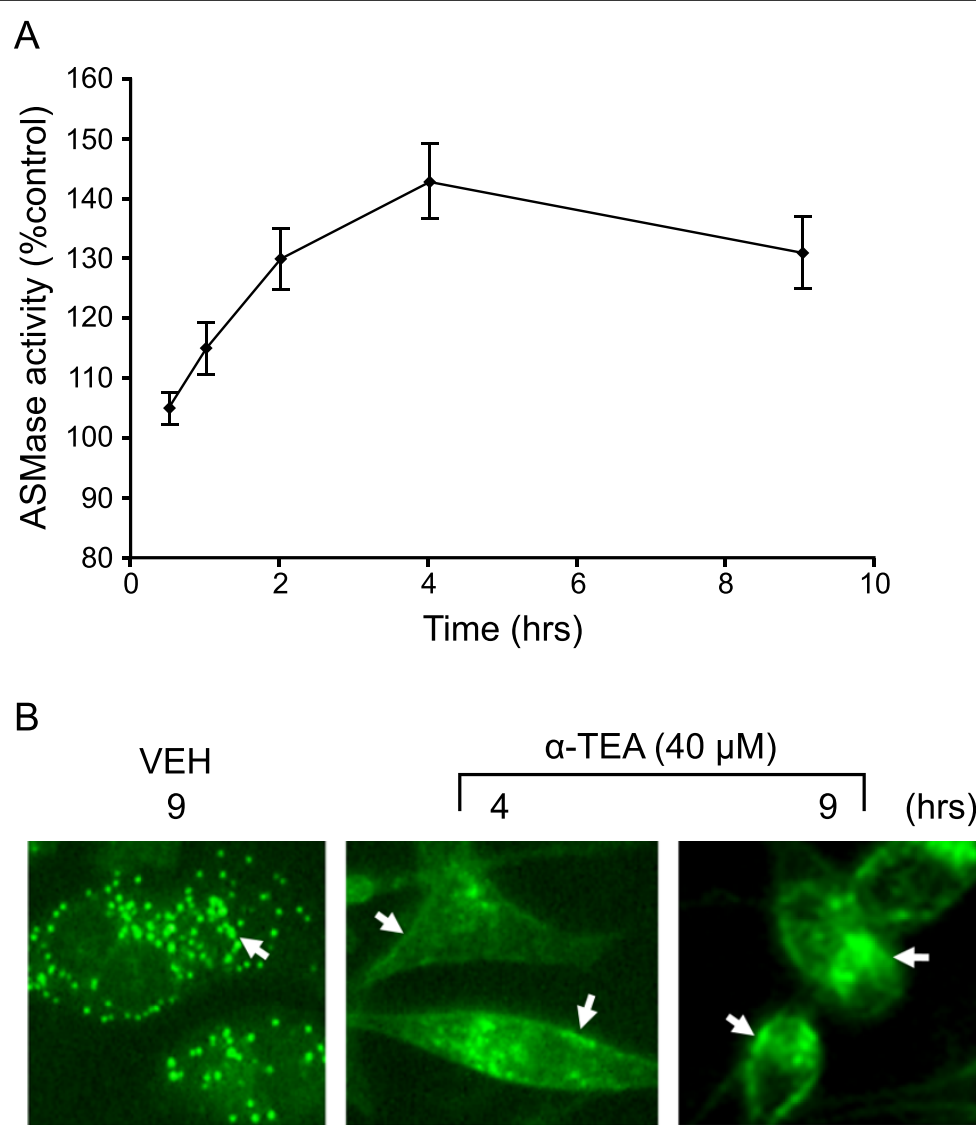

Anti-ASMase

Figure $4 \boldsymbol{\alpha}$-TEA induces ASMase activation. A, ASMase activity was detected using the Acid Sphingomyelinase Assay kit (Echelon) at different time points following treatment with $40 \mu \mathrm{M} \alpha$-TEA. B, Cellular localization of ASMase following treatment with $40 \mu \mathrm{M} \alpha$-TEA for 4 and 9 hrs (9 hrs vehicle treatment) was detected (green channel) using immunofluorescent staining of paraformaldehyde fixed cells. Arrows in $\alpha$-TEA treated cells point to membrane ASMase versus arrows in vehicle control point to cellular dispersion of ASMase.

suppression of anti-apoptotic mediators Akt, ERK, cFLIP and survivin $[15,16,18,20,21,28,29]$. However, less is known about initiating events that lead to these desirable dual activities. New findings reported here include: 1) $\alpha$-TEA triggers ASMase activation which involves translocation from cytosol to the cell surface membrane; 2) ASMase activation proceeds $\alpha$-TEA-induced increase levels and aggregation of ceramide in the cell surface membrane; 3) $\alpha$-TEA induces accumulation of DR5, Fas and FADD in elevated ceramide-enriched membrane; and 4) ASMase inhibitors (desipramine and siRNA to ASMase) decrease $\alpha$-TEA-mediated membrane changes and apoptosis.

Based on these data we propose the following sequence of events whereby $\alpha$-TEA induces apoptosis in human MDA-MB-231 breast cancer cells (summarized in Figure 9). Within $30 \mathrm{~min}$ of $\alpha$-TEA treatment ASMase activity starts to increase, and by 4 hrs there is evidence of ASMase translocation from the cytosol (intracellular compartments such as lysosomes) to the cell surface membrane. ASMase translocation is associated with increased levels of cell surface membrane ceramide. Co-localization of ceramide with Fas, DR5, and FADD and evidence of cleaved caspases 8 and 9 are observed by 9 and 15 hrs, while evidence of apoptosis (Annexin V expression and PARP cleavage) is observed at 15 and 24 hrs. Inhibition of ASMase activity using desipramine or ASMase expression using siRNA reduces the ability of $\alpha$-TEA to increase cell surface membrane levels of ceramide, DR5, Fas and FADD and reduces $\alpha$-TEA-induced apoptosis. In summary, $\alpha$-TEAinduced apoptosis triggers an early ASMase-dependent generation of ceramide in the cell surface membrane of human MDA-MB-231 breast cancer cells, which is required for Fas and FADD relocation to the cell surface membrane and DR5, Fas and FADD co-localization in ceramide-enriched membrane domains.

The concept that vitamin $\mathrm{E}$ analogs can increase sphingomyelinase activity and ceramide in conjunction with apoptosis induction has been reported previously in other cancer cell types [30,31]. Weber et al. [30] showed that Jurkat human $\mathrm{T}$ lymphoma cells treated 


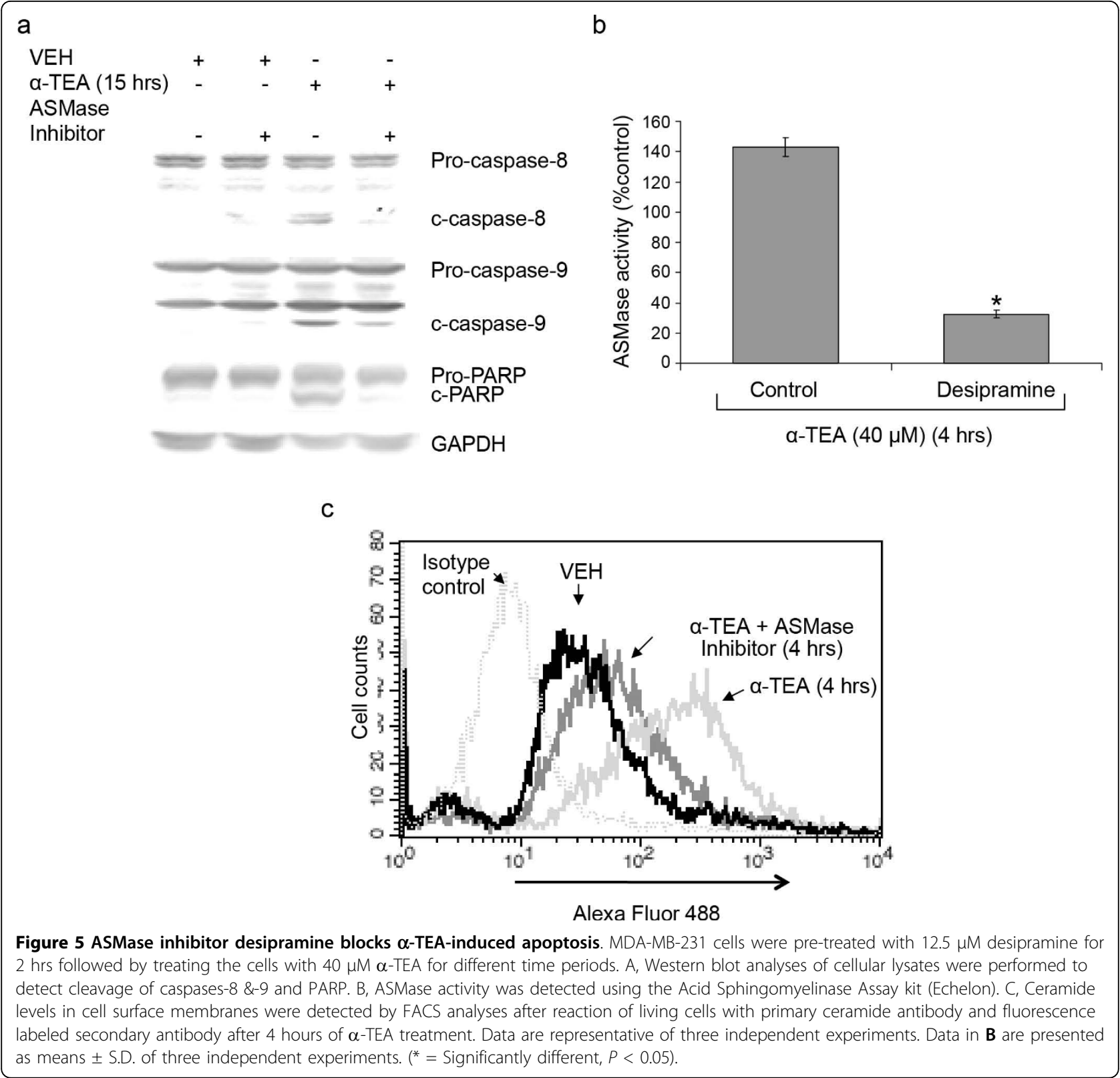

with the vitamin E analog, RRR-alpha-tocopheryl succinate (called vitamin E succinate), exhibited altered mitochondrial structure, generation of free radicals, and activation of the sphingomyelin cycle as early events in vitamin E succinate-initiated pro-apoptotic signaling. Based on a partial suppression of vitamin E succinateinduced apoptosis by the ASMase inhibitor desipramine, they demonstrated that activation of ASMase played a role in vitamin E succinate-induced apoptosis [30]. Our data are in agreement showing that ASMase activation is involved in apoptosis induced by another vitamin $\mathrm{E}$ derivative, $\alpha$-TEA. Thus, activation of ASMase may be a common event in vitamin $\mathrm{E}$ analog-induced apoptosis that is not cell type specific. Likewise, our data are in agreement with the studies of Gu et al. [31] who showed that vitamin E succinate-induced apoptosis in human head and neck squamous cell carcinomas (HNSCC) was correlated with early increases in sphingomyelinase activity and ceramide levels. Furthermore, our data showing increased immunostaining of ceramide within cell surface membranes of tumor tissue derived from breast cancer bearing immune compromised mice fed $\alpha$-TEA are in agreement with $\mathrm{Gu}$ et al.'s data showing a significant degree of immune staining of ceramide within the cellular membrane of HNSCC JHU-022 tumor tissue obtained from xenografted immune 


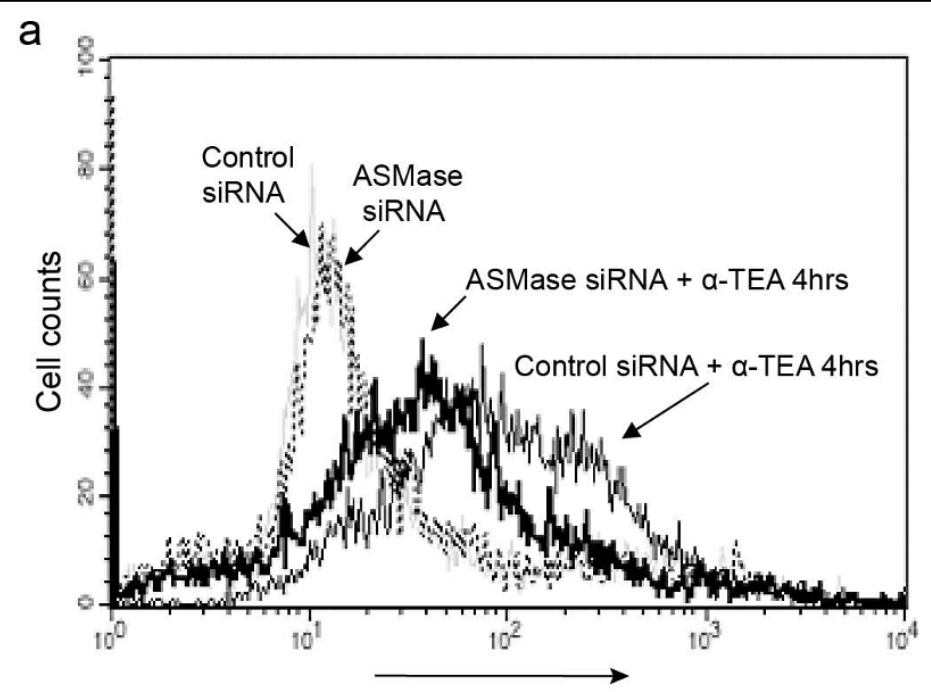

Alexa Fluor 488

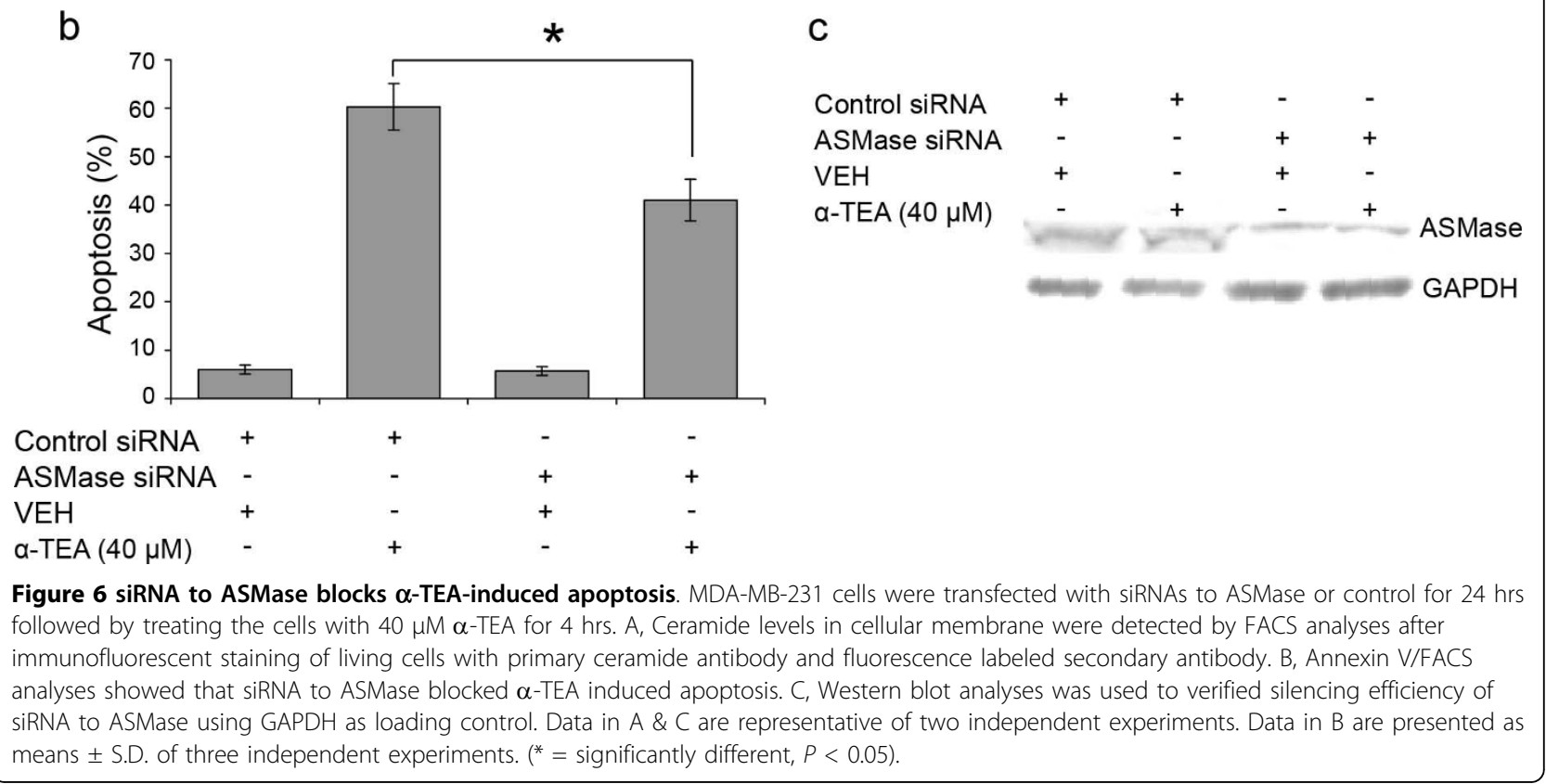

compromised mice injected i.p. with vitamin E succinate [31]. Thus, the ability of vitamin $E$ analogs to induce elevated cell surface membrane levels of ceramide in cancer cells occurs both in cell culture and in vivo [31].

An important difference between the studies reported here and the studies cited above, is that we report a connection between early activation of ASMase and subsequent elevated cell surface membrane ceramide with co-localization with Fas, DR5 and FADD in membrane. Previously, we showed that $\alpha$-TEA treatments increased Fas and Fas L mRNA and protein levels, as well as levels of cell surface membrane-associated Fas in human ovarian and prostate cancer cells and that functional knockdown of Fas and Fas-L attenuated $\alpha$-TEA-induced apoptosis $[20,21]$. Recently, we showed that $\alpha$-TEA treatment increases the expression of TRAIL and DR5 and that functional knockdown of DR5 and TRAIL blocked $\alpha$-TEA's ability to induce apoptosis $[15,16]$. Thus, data suggest that $\alpha$-TEA induction of apoptosis involves, at least in part, activation of extrinsic death receptor signaling. Information reported here suggests that $\alpha$-TEA triggering of apoptosis via extrinsic death receptors involves upregulation of ceramide-enriched membrane domains via activation of ASMase. 


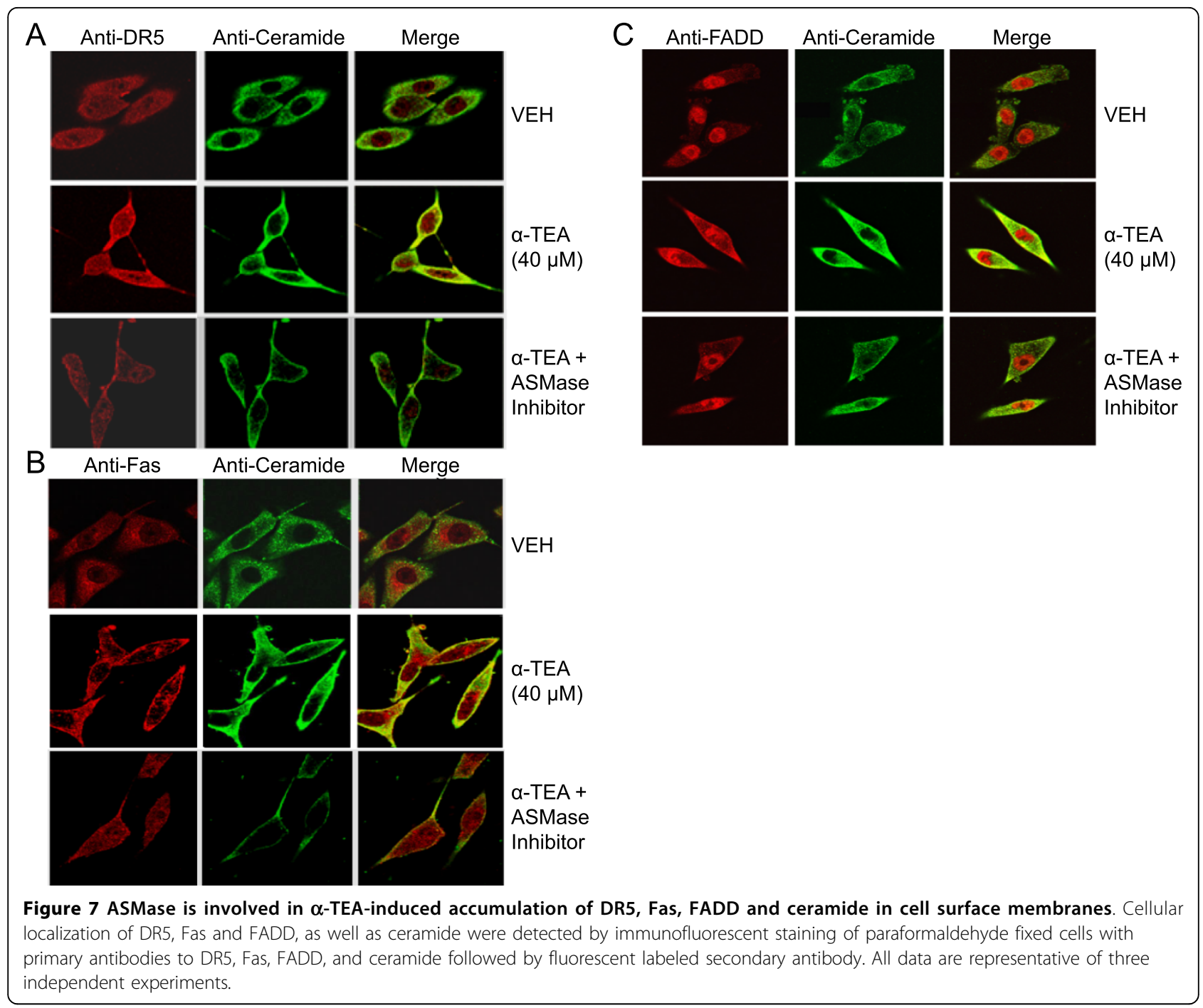

Increases in cell surface membrane ceramide levels occur via sphingomyelinase catalyzed hydrolysis of sphingomyelin at the membrane. ASMase exists in two forms, a lysosomal and a secretory form [32]. Secretory ASMase translocates onto the outer leaflet of the plasma membrane from an intracellular location, presumably vesicular stores, to release ceramide within the raft-associated sphingomyelin pool, generating the ceramide required for raft clustering in response to various stress stimuli, including irradiation, death receptors signaling, and chemotherapeutic agents such as cisplatin and doxorubicin [32-38]. Therefore, ceramide in the cell surface membrane can function as an upstream or downstream mediator of extrinsic death receptor mediated apoptosis. Fas ligand and TRAIL have been shown to trigger accumulation of ceramide in membranes via recruitment of DISC and activation of caspase $8[33,34,38]$, while another study showed that UV-induced accumulation of ceramide is FADD/caspase-8 independent [32]. Furthermore, ceramide-mediated formation of Fas- or DR5clusters within the ceramide platform leads to triggering of death receptor-mediated apoptosis [4,9,33-35] which can be either ligand-dependent or -independent [32]. Data presented here show that increased levels and aggregation of membrane ceramide occur as early as 4 hrs after $\alpha$-TEA treatment, while DR5/Fas/FADD membrane accumulation was not observed until 9 hrs after $\alpha$-TEA treatment, suggesting that ceramide increase and aggregation may be an upstream event in $\alpha$-TEAinduced Fas- and DR5-mediated apoptosis.

Several mechanisms have been proposed to be involved in the activation of ASMase, including ROS $[33,39]$, lysosomal anionic lipids (bismonoacylglycerophosphate) and sphingolipid activator protein SAP-C [40]. Recent data show that $\mathrm{PKC} \delta$ contributes to the translocation and activation of ASMase via 


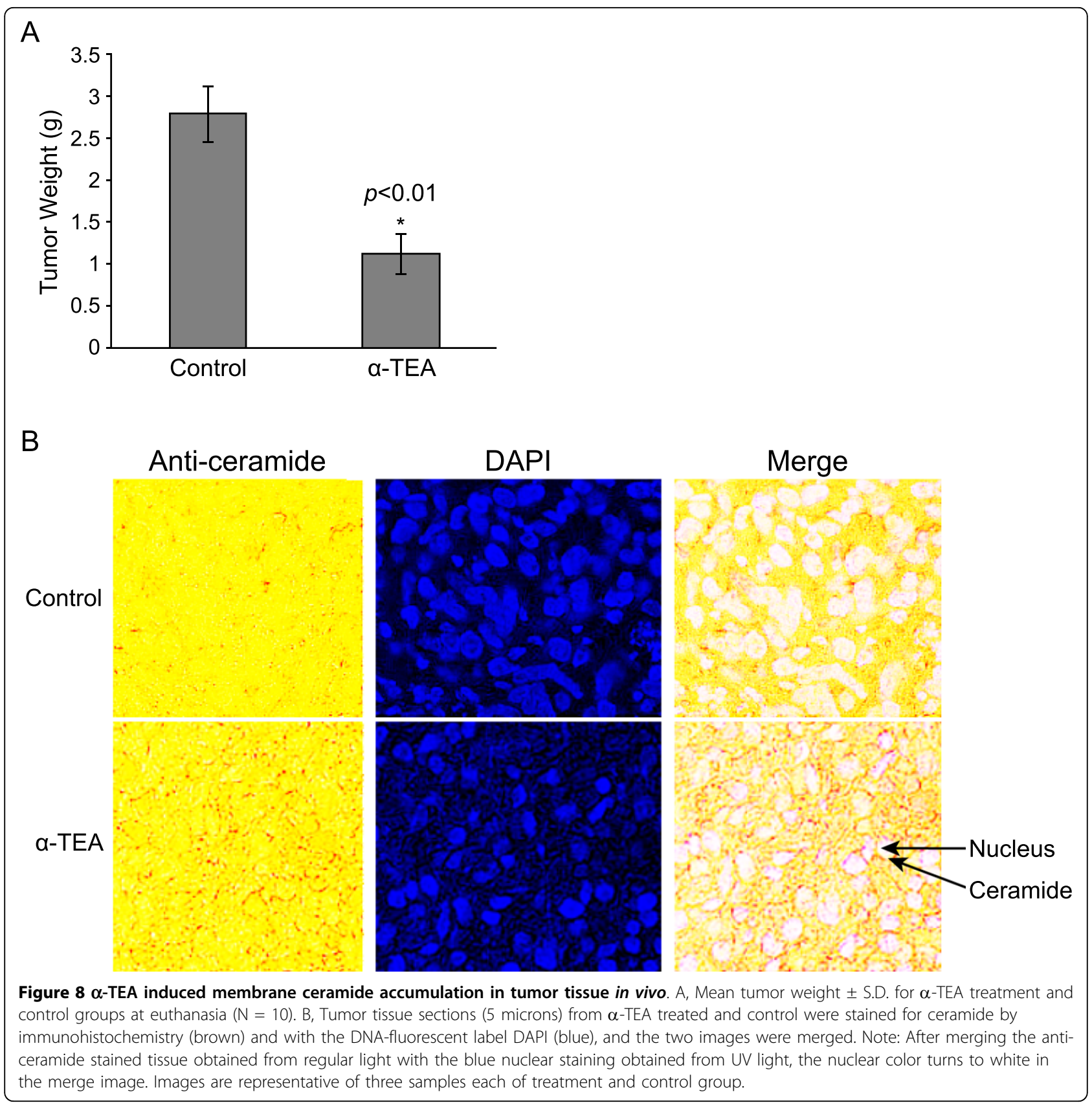

phosphorylation of ASMase at ser-508 by PMA [37]. How $\alpha$-TEA regulates ASMase activation is not known. Our preliminary data do not support the role of ROS in $\alpha$-TEA-induced ASMase activation since ROS was not induced by $\alpha$-TEA and the antioxidant NAC did not block $\alpha$-TEA-induced increases in the levels of membrane ceramide (data not shown). Since $\alpha$-TEA is a detergent-like lipid it is possible that $\alpha$-TEA targets lysosomes initiating activation of ASMase. This remains to be determined.
Ceramide action is determined within the context of other stimuli and by the subcellular location of its production. Beside ASMase hydrolysis of sphingomyelin to mediate ceramide levels at the cell surface, there are two more pathways in which intracellular ceramide can be generated, namely, the de novo synthesis pathway (located in the endoplasmic reticulum) and the salvage pathway (located in late endosomes/lysosomes) [41]. Both of these pathways generate ceramide and others metabolites, which may contribute to apoptosis 


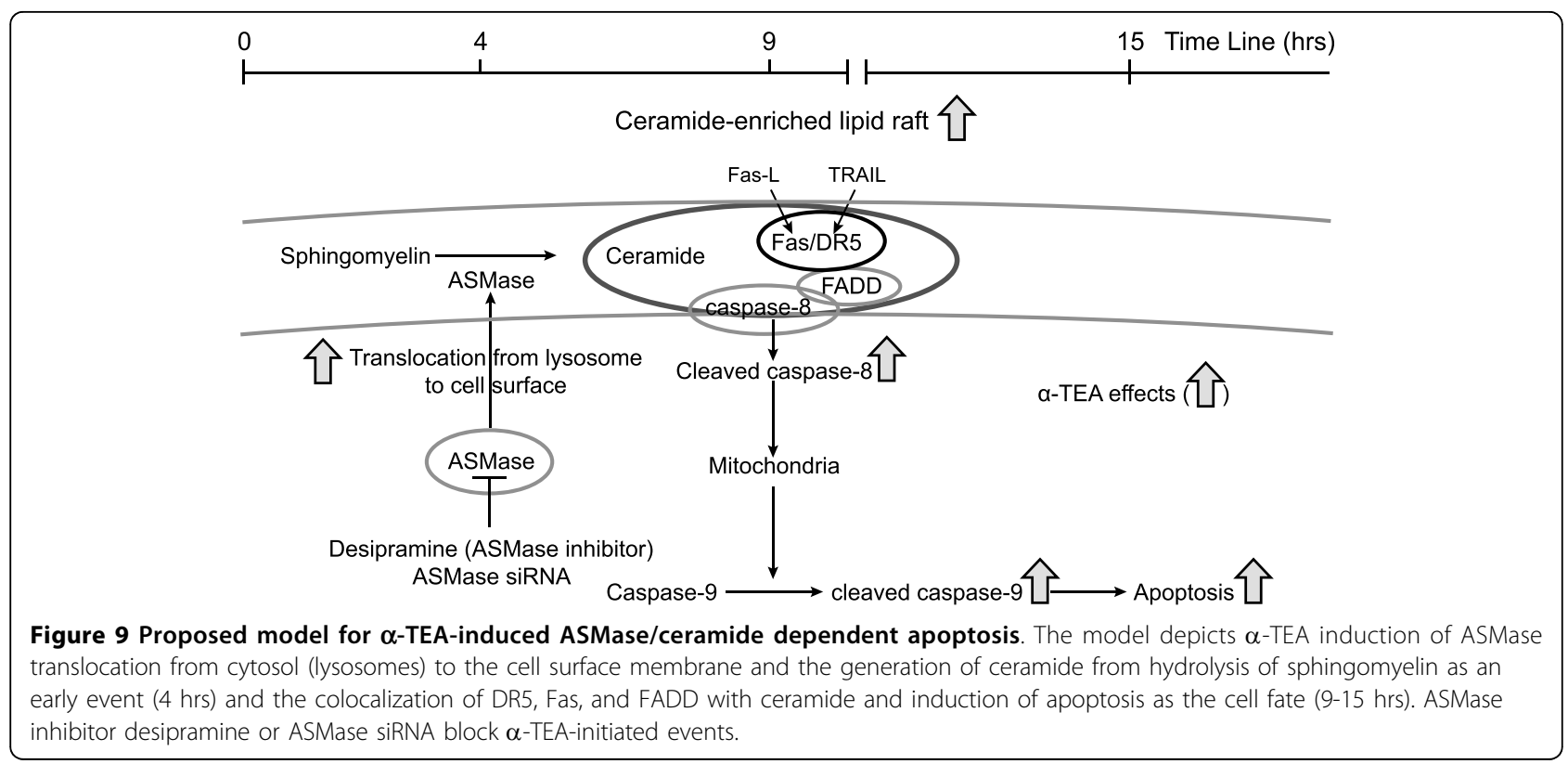

induction via mechanisms that differ from ceramide's role at the cell surface. For example; dihydroceramide, an intermediate in the de novo synthesis pathway, has been reported to trigger apoptosis and is upregulated by $\gamma$-tocopherol [42]. Glucosylceramide, an intermediate in the salvage pathway, shows anti-apoptotic properties and can be converted to ceramide by cerebrosidase (glucohydrolases) [43]. Whether $\alpha$-TEA regulates these pathways is not known and beyond the scope of this studies; however, we do know that de novo synthesis pathway is not involved in $\alpha$-TEA-induced apoptosis based on the fact that the de novo ceramide synthesis inhibitors myriocin and fumonisin B1 did not block $\alpha$ TEA-induced apoptosis (data not shown). These inhibitor studies also suggest that ceramide synthase-mediated ceramide may not be involved in $\alpha$-TEA-induced apoptosis since fumonisin B1, an inhibitor of ceramide synthase, did not block $\alpha$-TEA- induced apoptosis.

To study how $\alpha$-TEA regulates ceramide levels in cellular membranes we used anti-ceramide antibody (15B4), which provides special benefit to study ceramide in its cellular context, such as subcellular localization of ceramide. Although this antibody has been used in many studies, the specificity of this antibody is still questioned. For example, lipid overlay assays show that the 15B4 anti-ceramide antibody recognizes not only C16- and C24-ceramide, but also other lipids such as dihydroceramide, sphingomyelin and phosphatidylcholine [44]. However, it is highly specific for ceramide and does not cross-react with sphingomyelin, cholesterol or other phospholipids under more physiologically relevant in vitro and in vivo conditions $[34,44]$. In the studies reported here, both ASMase inhibitor desipramine and
siRNA to ASMase blocked $\alpha$-TEA-induced increases in 15B4 antibody-recognized phospholipids in membrane clearly indicating that anti-ceramide (15B4) is specific for recognizing membrane ceramide and confirming that $\alpha$-TEA effects are dependent on ASMase-mediated ceramide increases in membrane.

\section{Conclusion}

In summary, our findings demonstrate that activation of ASMase, leading to increases in cell surface membrane ceramide, is a critical early event for extrinsic death receptor signaling in $\alpha$-TEA-induced apoptosis. This is the first study that identifies possible initiation event in $\alpha$-TEA-induced apoptosis.

\section{Abbreviations}

ASMase: acid sphingomyelinase; $\alpha$-TEA: Alpha-tocopherol ether-linked acetic acid analog; DISC: death inducing signaling complex; DR5: Death receptor 5; FADD: Fas-Associated protein with Death Domain; TRAIL: TNF related apoptosis induced ligand.

\section{Acknowledgements}

This work was supported by Public Health Service Grant CA59739 (BGS and KK), the Clayton Foundation for Research (BGS and KK), the National Institute of Environmental Health Sciences Center Grant ES007784 (BGS and KK), Center for Molecular and Cellular Toxicology at the University of Texas at Austin (BGS and KK) and a NIEHS/NIH Toxicology Training Grant T32 ES07247 (RT). The funding sources have no role in the decision to submit the manuscript for publication.

\section{Author details}

${ }^{1}$ School of Biological Sciences/C0900, University of Texas at Austin, Austin, TX 78712, USA. ${ }^{2}$ Department of Nutritional Sciences/A2703, University of Texas at Austin, Austin, TX 78712, USA.

\section{Authors' contributions}

JL carried out immuno-fluorescent assays, ceramide detection, ASmase detection assay, Annexin $\vee$ staining and drafted the manuscript. WY 
conceived the study, participated in the design, performed the statistical analysis, carried out cell culture and drafted/revised the manuscript. RT carried out western blot assays. SKP provided technical help with detection of ceramide expression and apoptosis assay. AX helped in cell culture. BGS and KK conceived the study, drafted/revised the manuscript and provided critical analysis. All authors read and approved the final manuscript.

\section{Competing interests}

US and international patents on $\alpha$-TEA are held by the Research Development Foundation. Kimberly Kline and Bob G. Sanders are listed as inventors. No commercial applications or financial gain have been realized.

Received: 26 May 2010 Accepted: 25 October 2010

Published: 25 October 2010

\section{References}

1. Zhang Y, Li X, Becker KA, Gulbins E: Ceramide-enriched membrane domains-structure and function. Biochim Biophys Acta 2009, 1788:178-83.

2. Smith EL, Schuchman EH: The unexpected role of acid sphingomyelinase in cell death and the pathophysiology of common diseases. FASEB J 2008, 22:3419-31.

3. Carpinteiro A, Dumitru C, Schenck M, Gulbins E: Ceramide-induced cell death in malignant cells. Cancer Lett 2008, 264:1-10.

4. Grassme H, Cremesti A, Kolesnick R, Gulbins E: Ceramide-mediated clustering is required for CD95-DISC formation. Oncogene 2003, 22:5457-5470.

5. Dumitru CA, Carpinteiro A, Trarbach T, Hengge UR, Gulbins E: Doxorubicin enhances TRAIL-induced cell death via ceramide-enriched membrane platforms. Apoptosis 2007, 12:1533-41.

6. Bollinger CR, Teichgraber V, Gulbins E: Ceramide-enriched membrane domains. Biochimica Biophysica Acta 2005, 1746:284-294.

7. Wilson NS, Dixit V, Ashkenazi A: Death receptor signal transducers: nodes of coordination in immune signaling networks. Nature Immunol 2009, 10:348-55

8. Chinnaiyan AM, O'Rourke K, Tewari M, Dixit VM: FADD, a novel death domain-containing protein, interacts with the death domain of Fas and initiates apoptosis. Cell 1995, 81:505-12.

9. Grassme H, Schwarz H, Gulbins E: Molecular mechanisms of ceramidemediated CD95 clustering. Biochem Biophy Res Comm 2001, 284:1016-30.

10. Lawson KA, Anderson K, Simmons-Menchaca M, et al: Novel vitamin E analogue decreases syngeneic mouse mammary tumor burden and reduces lung metastasis. Mol Cancer Ther 2003, 2:437-44.

11. Lawson KA, Anderson K, Simmons-Menchaca M, Sun LZ, Sanders BG, Kline K: Comparison of vitamin E derivatives a-TEA and VES in reduction of mouse mammary tumor burden and metastasis. Exp Biol Med 2004, 229:954-63.

12. Lawson KA, Anderson K, Snyder RM, et al: Vitamin E analogue and 9-nitrocamptothecin administered as liposome aerosols decrease syngeneic mouse mammary tumor burden and inhibit metastasis. Cancer Chemother Pharmacol 2004, 54:421-31.

13. Zhang S, Lawson KA, Simmons-Menchaca M, Sun L, Sanders BG, Kline K: Vitamin $E$ analog $a-T E A$ and celecoxib alone and together reduce human MDA-MB-435-FL-GFP breast cancer burden and metastasis in nude mice. Breast Cancer Res Treat 2004, 87:111-21.

14. Anderson K, Lawson KA, Simmons-Menchaca M, Sun L, Sanders BG, Kline K: a-TEA plus cisplatin reduces human cisplatin-resistant ovarian cancer cell tumor burden and metastasis. Exp Biol Med 2004, 229:1169-76.

15. Yu W, Tiwary R, Li G, Park SK, Jia L, Xiong A, Simmons-Menchaca M, Sanders BG, Kline K: a-TEA induces apoptosis of human breast cancer cells via activation of TRAIL/DR5 death receptor pathway. Mol. Carcinogenesis 2010.

16. Tiwary R, Yu W, Li J, Park SK, Sanders BG, Kline K: Role of endoplasmic reticulum stress in alpha-TEA mediated TRAIL/DR5 death receptor dependent apoptosis. PLoS One 2010, 29;5(7):e11865.

17. Anderson K, Simmons-Menchaca M, Lawson KA, Atkinson J, Sanders BG, Kline K: Differential response of human ovarian cancer cells to induction of apoptosis by vitamin E succinate and vitamin E analogue, a-TEA. Cancer Res 2004, 15:4263-9.

18. Shun MC, Yu W, Gapor A, et al: Pro-apoptotic mechanisms of action of a novel vitamin $E$ analog ( $a-T E A)$ and a naturally occurring form of vitamin $\mathrm{E}$ (a-tocotrienol) in MDA-MB-435 human breast cancer cells. Nutr Cancer 2004, 48:95-105.

19. Hahn T, Szabo L, Gold M, Ramanathapuram L, Hurley LH, Akporiaye ET: Dietary administration of the proapoptotic vitamin $\mathrm{E}$ analogue $\mathrm{a}$ tocopheryloxyacetic acid inhibits metastatic murine breast cancer. Cancer Res 2006, 66:9374-8.

20. Yu W, Shun M, Anderson $K$, Chen $H$, Sanders BG, Kline K: $a-T E A$ inhibits survival and enhances death pathways in cisplatin sensitive and resistant human ovarian cancer cells. Apoptosis 2006, 11:1813-23.

21. Jia L, Yu W, Wang P, Sanders BG, Kline K: Critical roles for JNK, C-Jun, and Fas/FasL-signaling in vitamin $\mathrm{E}$ analog-induced apoptosis in human prostate cancer cells. Prostate 2008, 68:427-41.

22. Jia L, Yu W, Wang P, Sanders BG, Kline K: In vivo and in vitro studies of anticancer actions of a-TEA for human prostate cancer cells. Prostate 2008, 68:849-60.

23. Yu W, Jia L, Park SK, Li J, Gopalan A, Simmons-Menchaca M, Sanders BG, Kline $\mathrm{K}$ : Anticancer actions of natural and synthetic vitamin $\mathrm{E}$ forms: RRRalpha-tocopherol blocks the anticancer actions of gamma-tocopherol. Mol Nutr Food Res 2009, 53:1573-81.

24. Hahn T, Fried K, Hurley LH, Akporiaye ET: Orally active atocopheryloxyacetic acid suppresses tumor growth and multiplicity of spontaneous murine breast cancer. Mol Cancer Ther 2009, 8:1570-8.

25. Latimer P, Menchaca M, Snyder RM, Yu W, Gilbert BE, Sanders BG, Kline K: Aerosol delivery of liposomal formulated paclitaxel and vitamin $E$ analog reduces murine mammary tumor burden and metastases. Exp Biol Med (Maywood) 2009, 234:1244-52.

26. Yu W, Israel K, Liao QY, Aldaz CM, Sanders BG, Kline K: Vitamin E succinate (VES) induces Fas sensitivity in human breast cancer cells: role for $\mathrm{Mr}$ 43,000 Fas in VES-triggered apoptosis. Cancer Res 1999, 59:953-61.

27. Yu W, Jia L, Park SK, et al: Anticancer actions of natural and synthetic vitamin E forms: RRR-a-tocopherol blocks the anticancer actions of atocopherol. Mol Nutr Food Res 2009, 53:1573-1581.

28. Wang P, Yu W, Hu Z, Jia L, lyer VR, Sanders BG, Kline K: Involvement of $\mathrm{JNK} / \mathrm{p} 73 / \mathrm{NOXA}$ in vitamin $\mathrm{E}$ analog-induced apoptosis of human breast cancer cells. Mol Carcinogen 2008, 47:436-45.

29. Snyder RM, Yu W, Jia L, Sanders BG, Kline K: Vitamin E analog a-TEA, methylseleninic acid, and trans-resveratrol in combination synergistically inhibit human breast cancer cell growth. Nutr Cancer 2008, 60:401-11.

30. Weber $T$, Dalen $H$, Andera $L$, et al: Mitochondria play a central role in apoptosis induced by a-tocopheryl succinate, an agent with antineoplastic activity: comparison with receptor-mediated proapoptotic signaling. Biochem 2003, 42:4277-91.

31. Gu X, Song X, Dong Y, et al: Vitamin E succinate induces ceramidemediated apoptosis in head and neck squamous cell carcinoma in vitro and in vivo. Clin Cancer Res 2008, 14:1840-8.

32. Rotolo JA, Zhang J, Donepudi M, Lee H, Fuks Z, Kolesnick R: Caspasedependent and -independent activation of acid sphingomyelinase signaling. J Biol Chem 2005, 280:26425-34

33. Dumitru CA, Gulbins E: TRAIL activates acid sphingomyelinase via a redox mechanism and releases ceramide to trigger apoptosis. Oncogene 2006, 25:5612-25.

34. Grassme $H$, Jekle A, Riehle A, et al: CD95 signaling via ceramide-rich membrane rafts. J Biol Chem 2001, 276:20589-96.

35. Radin NS: Killing tumors by ceramide-induced apoptosis: a critique of available drugs. Biochem J 2003, 37:243-256.

36. Jin S, Yi F, Zhang F, Poklis JL, Li PL: Lysosomal targeting and trafficking of acid sphingomyelinase to lipid raft platforms in coronary endothelial cells. Arterioscler Thromb Vasc Biol 2008, 28:2056-62.

37. Zeidan $\mathrm{YH}$, Hannun YA: Activation of acid sphingomyelinase by protein kinase C delta-mediated phosphorylation. J Biol Chem 2007, 282:11549-61.

38. Gulbins E: Regulation of death receptor signaling and apoptosis by ceramide. Pharmacol Res 2003, 47:393-9.

39. Charruyer A, Grazide S, Bezombes C, Muller S, Laurent G, Jaffrezou JP: UV-C light induces raft-associated acid sphingomyelinase and JNK activation and translocation independently of a nuclear signal. J Biol Chem 2005, 280:19196-19204.

40. Linke T, Wilkening G, Lansmann S, et al: Stimulation of acid sphingomyelinase activity by lysosomal lipids and sphingolipid activator proteins. Biol Chem 2001, 382:283-90. 
41. Kitatani K, Idkowiak-Baldys J, Hannun YA: The sphingolipid salvage pathway in ceramide metabolism and signaling. Cell Signal 2008, 20:1010-8.

42. Jiang $\mathrm{Q}$, Wong J, Fyrst $\mathrm{H}$, Saba JD, Ames BN: gamma-Tocopherol or combinations of vitamin $\mathrm{E}$ forms induce cell death in human prostate cancer cells by interrupting sphingolipid synthesis. Proc Natl Acad Sci USA 2004, 101:17825-30.

43. Kitatani K, Sheldon K, Rajagopalan V, Anelli V, Jenkins RW, Sun Y, Grabowski GA, Obeid LM, Hannun YA: Involvement of acid betaglucosidase 1 in the salvage pathway of ceramide formation. $J$ Biol Chem 2009, 284:12972-8.

44. Cowart LA, Szulc Z, Bielawska A, Hannun YA: Structural determinants of sphingolipid recognition by commercially available anti-ceramide antibodies. J Lipid Res 2002, 43:2042-8.

doi:10.1186/1475-2867-10-40

Cite this article as: Li et al: $\alpha$-TEA-induced death receptor dependent apoptosis involves activation of acid sphingomyelinase and elevated ceramide-enriched cell surface membranes. Cancer Cell International 2010 10:40.

\section{Submit your next manuscript to BioMed Central} and take full advantage of:

- Convenient online submission

- Thorough peer review

- No space constraints or color figure charges

- Immediate publication on acceptance

- Inclusion in PubMed, CAS, Scopus and Google Scholar

- Research which is freely available for redistribution

Submit your manuscript at www.biomedcentral.com/submit 